\title{
Infection Control Hospital Epidemiology
}

SHEA

The Society for Healthcar

Epidemiology of America

Volume 40, No 7
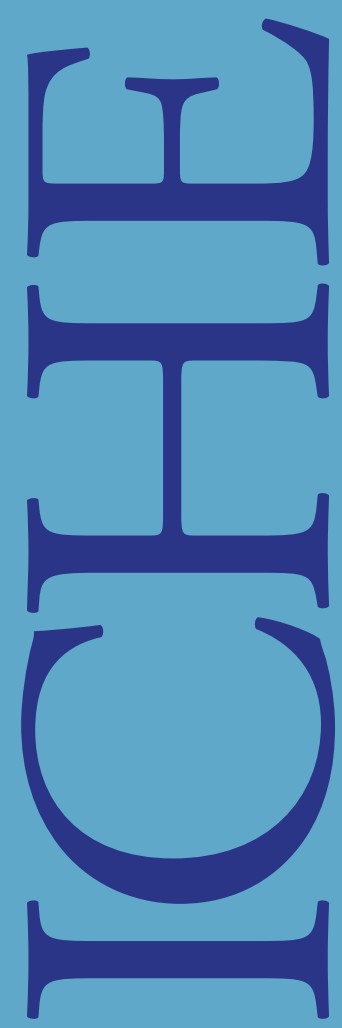

JULY 2019

MAIMONIDES

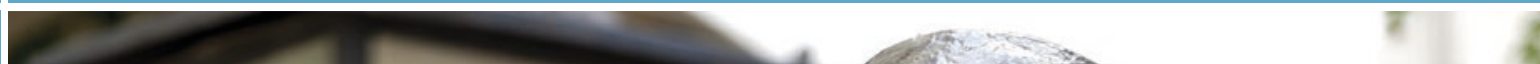




\section{CAMBRIDGE Medicine}

\section{Practical Implementation of an Antibiotic Stewardship Program}

Editors:

Tamar F. Barlam, Boston Medical Center

Melinda M. Neuhauser, Department of Veteran Affairs

Pranita D. Tamma, The Johns Hopkins University School of Medicire Kavita K. Trivedi, Trivedi Consults, LLC.

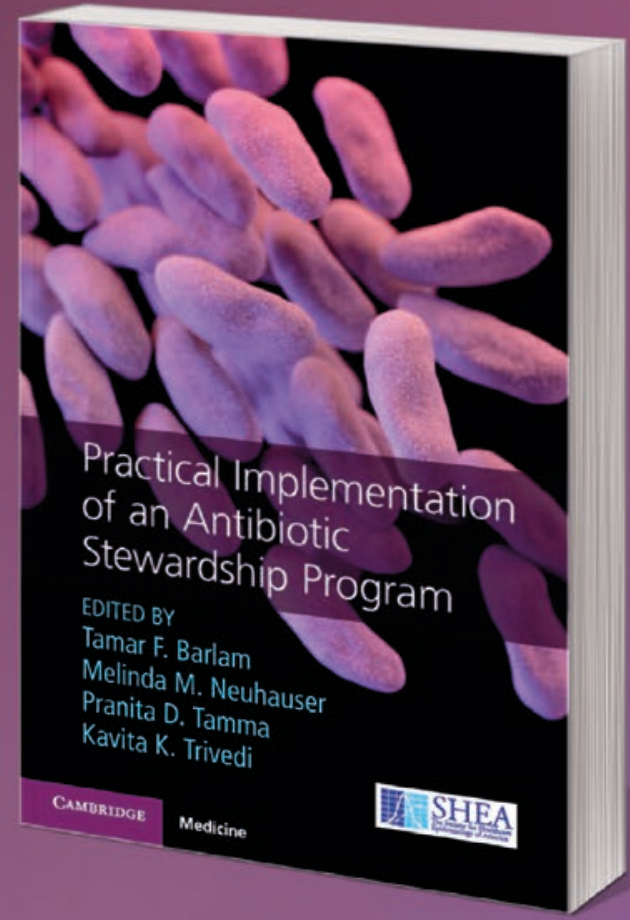

June 2018 / Hardback / 9781107166172

$\$ 64.99$ / £49.99
Practical Implementation of an Antibiotic Stewardship Program provides an essential resource for healthcare providers in acute care, long-term care, and ambulatory care settings looking either to begin or to strengthen existing antibiotic stewardship programs. Each chapter is written by both physician and pharmacist leaders in the stewardship field and incorporates both practical knowledge as well as evidence-based guidance. This book will also serve as a useful resource for medical students, pharmacy students, residents, and infectious diseases fellows looking to learn more about the field of antibiotic stewardship.

- Presents a practical guide for the implementation of antibiotic stewardship programs

- Offers real-life experience from experts in developing and sustaining antibiotic stewardship programs

- Incorporates both practical experience and evidence-based guidance to implement effective antibiotic stewardship programs in the acute care, long-term care, and ambulatory care settings
For more information, please go to cambridge.org/antibioticstewardshipprogram 


\title{
CONTENTS
}

\author{
Original Articles
}

741 Impact of an automated hand hygiene monitoring system and additional promotional activities on hand hygiene performance rates and healthcare-associated infections

John M. Boyce, Jennifer A. Laughman, Michael H. Ader, Pamela T. Wagner, Albert E. Parker and James W. Arbogast

748 The effect of eye images and a social norms message on healthcare provider hand hygiene adherence Sarah A. Stella, Roger J. Stace, Bryan C. Knepper, Sara M. Reese, Angela Keniston, Marisha Burden and Heather L. Young

755 Association between universal gloving and healthcare-associated infections: A systematic literature review and meta-analysis

Nai-Chung N. Chang, Ashley E. Kates, Melissa A. Ward, Elizabeth J. Kiscaden, Heather Schacht Reisinger, Eli N. Perencevich and Marin L. Schweizer for the CDC Prevention Epicenters Program

761 Effectiveness of a multisite personal protective equipment (PPE)-free zone intervention in acute care Lindsay D. Visnovsky, Yue Zhang, Molly K. Leecaster, Nasia Safdar, Lauren Barko, Candace Haroldsen, Diane L. Mulvey, McKenna Nevers, Catherine Shaughnessy, Kristina M. Stratford, Frank A. Drews, Matthew H. Samore and Jeanmarie Mayer

767 Use of a cohorting-unit and systematic surveillance cultures to control a Klebsiella pneumoniae carbapenemase (KPC)-producing Enterobacteriaceae outbreak Allison E. Reeme, Sarah L. Bowler, Blake W. Buchan, Mary Beth Graham, Elizabeth Behrens, Siddhartha Singh, Johnny C. Hong, Jennifer Arvan, Joshua W. Hyke, Louis Palen, Sabrina Savage, Heather Seliger, Susan Huerta, Nathan A. Ledeboer, Shireen Kotay, Amy J. Mathers, Vaughn S. Cooper, Mustapha Munir Mustapha, Roberta T. Mettus, Yohei Doi and L. Silvia Munoz-Price

774 Decrease in vancomycin-resistant Enterococcus colonization associated with a reduction in carbapenem use as empiric therapy for febrile neutropenia in patients with acute leukemia Clyde D. Ford, Jana Coombs, Michaela Gazdik Stofer, Bert K. Lopansri, Brandon J. Webb, Fabiana Ostronoff, Julie Asch and Daanish Hoda

780 Antimicrobial resistance patterns of urine culture specimens from 27 nursing homes: Impact of a two-year antimicrobial stewardship intervention Meera Tandan, Philip D. Sloane, Kimberly Ward, David J. Weber, Akke Vellinga, Christine E. Kistler, and Sheryl Zimmerman

787 Bacillus cereus infection in neonates and the absence of evidence for the role of banked human milk: Case reports and literature review Antoine Lewin, Caroline Quach, Virginie Rigourd, Jean-Charles Picaud, Thérèse Perreault, Pierre Frange, Marc-Christian Domingo, Cindy Lalancette, Gilles Delage and Marc Germain 


\section{Concise Communications}

794 Evaluating accuracy of sampling strategies for fluorescent gel monitoring of patient room cleaning Clare Rock, Bryce A. Small, Yea-Jen Hsu, Ayse P. Gurses, Anping Xie, Verna Scheeler, Stephanie Cummings, Polly Trexler, Aaron M. Milstone, Lisa L. Maragakis and Sara E. Cosgrove for the CDC Prevention Epicenters Program

798 Implementation of cleaning and evaluation process for mobile patient equipment using adenosine triphosphate

Sara M. Reese, Bryan C. Knepper, Jennifer Kurtz, D. Christy LeQuire, Tina Van Winks, Jennifer Bonn and Heather L. Young

801 A national survey of testing and management of asymptomatic carriage of $C$. difficile

Preeta K. Kutty, Susan E. Beekmann, Ronda L. Sinkowitz-Cochran, Erik R. Dubberke, David T. Kuhar,

L. Clifford McDonald and Philip M. Polgreen

804 Use of whole-genome sequencing to guide a Clostridioides difficile diagnostic stewardship program Kunal K. Jakharia, Ghassan Ilaiwy, Siobhan S. Moose, Masashi Waga, Lakshmi Appalla, Joel D. McAlduff, Lynne V. Karanfil, Patrick T. McGann and Glenn W. Wortmann

807 Evaluation of an electronic antimicrobial time-out on antimicrobial utilization at a large health system Steven R. Richardson, Elizabeth A. Neuner, Vasilios Athans, Pavithra Srinivas, Jill Wesolowski, Steven M. Gordon and Thomas G. Fraser

810 Changes in antibiotic use following implementation of a telehealth stewardship pilot program Brigid M. Wilson, Richard E. Banks, Christopher J. Crnich, Emma Ide, Roberto A. Viau, Nadim G. El Chakhtoura, Yvonne R. Jones, Jason B. Cherry, Brett A. Anderson and Robin L. P. Jump

\section{Research Briefs}

815 Frequency of nursing home resident contact with staff, other residents, and the environment outside resident rooms

Lisa Pineles, Eli N. Perencevich, Mary-Claire Roghmann, Kalpana Gupta, Jose Cadena, Gio Baracco, Christopher D. Pfeiffer, Graeme Forrest, Suzanne F. Bradley, Chris Crnich, Heather S. Reisinger and Daniel J. Morgan

817 Validation of National Healthcare Safety Network-reported core elements of antimicrobial stewardship in Tennessee Christopher D. Evans, Katie A. Thure, Honour M. McDaniel, Cullen J. Adre, Vicky P. Reed, Pamela P. Talley and Marion A. Kainer

819 Potential utility of pharmacy data to measure antibiotic use in nursing homes Sarah Kabbani, Danielle L. Palms, Monina Bartoces, Joseph Marek, Nimalie D. Stone, Lauri A. Hicks and Robin L. P. Jump 
821 High rate of linezolid intermediate susceptibility and resistance among enteric vancomycin-resistant Enterococcus (VRE) recovered from hospitalized patients actively screened for VRE colonization Thomas J. Dilworth, Eric T. Beck, Rachel A. Pedersen, Waseem G. Al-Karkokly, Margaret M. Cook, Erika K. Aldag, David J. Kramer, Ajay K. Sahajpal, Iram Nadeem, Brian P. Buggy and Charles F. Brummitt

823 Predictive utility of swab screening for extended-spectrum beta-lactamase-producing organisms in selection of empiric antibiotics for Gram-negative sterile-site infections: A retrospective cohort study Ian A. Brasg, Marion Elligsen, Nick Daneman and Derek R. MacFadden

825 Lack of false-positive results for Clostridioides difficile toxins A and B using two commercial enzyme immunoassays in pediatric patients Aakash B. Balaji, Joseph S. Sichel and Larry K. Kociolek

826 Healthcare worker influenza vaccine waivers at an academic health system Abigail R. Sharpe, Megan LeClair-Netzel, Mallory Wagner, Nicole Kalscheur, Kate J. Berlin, Freddy Caldera and Mary S. Hayney

\section{Letters to the Editor}

829 Temperature, humidity, and climate control in hospital units: A clue for understanding the seasonality of healthcare-associated pathogens

Dayanne Conislla Limaylla, Marina de Oliveira Silva and Carlos Magno Castelo Branco Fortaleza

831 Appropriate use of chemical indicators in the steam sterilization process: Assured sterility and economy Debabrata Basu

832 Assessment of stool color in Clostridioides difficile infection: A pilot study Hiroshi Sugimoto, Kuniyoshi Hayashi, Keitaro Furukawa and Nobuyoshi Mori

834 Diagnosis of urinary tract infections: need for a reflective rather than reflexive approach Mohamad G. Fakih, Sonali D. Advani and Valerie M. Vaughn

836 Nontunneled central venous catheter bloodstream infections in pediatric surgery Marco Denina, Roberta Curetti, Silvia Garazzino, Erika Silvestro, Carlo Scolfaro and the Regina Margherita Children's Hospital Bloodstream Infections Study Group

\section{Corrigendum}

838 Clean care for all—it's in your hands: The May 5, 2019, World Health Organization's "SAVE LIVES: Clean Your Hands" campaign-CORRIGENDUM 
An Official Publication of the Society for Healthcare Epidemiology of America

\section{EDITOR}

Suzanne F. Bradley, MD • Ann Arbor, MI

\section{DEPUTY EDITOR}

Carol Chenoweth, MD • Ann Arbor, MI

\section{SENIOR ASSOCIATE EDITORS}

C. Glen Mayhall, MD • Galveston, TX

Gina Pugliese, RN, MS • Chicago, IL

William Schaffner, MD • Nashville, TN

\section{ASSOCIATE EDITORS}

David P. Calfee, MD, MS • New York, NY

Lindsay E. Nicolle, MD $\bullet$ Winnipeg, Manitoba

Trevor C. Van Schooneveld, MD • Omaha, NE

David Weber, MD, MPH $\bullet$ Chapel Hill, NC

\section{STATISTICS CONSULTANTS}

Jon P. Furuno, $\mathrm{PhD} \bullet$ Portland, OR

Jessina C. McGregor, $\mathrm{PhD} \bullet$ Portland, OR

\section{MANAGING EDITOR}

Lindsay MadMurray • New York, NY

\section{PAST EDITORS}

Infection Control $\bullet$ Portland, OR

Richard P. Wenzel, MD, 1980-1987 (vols. 1-8)

Infection Control \& Hospital Epidemiology

Richard P. Wenzel, MD, 1988-1992 (vols. 9-13)

Michael D. Decker, MD. 1993-2001 (vols. 14-22)

Barry M. Farr, MD, 2002-2004 (vols. 23-25)

William R. Jarvis, MD, 2005-2006 (vols. 26 and 27)

\section{EDITORIAL ADVISORY BOARD}

Deverick Anderson, MD, MPH $\bullet$ Durham, NC

\author{
Anucha Apisarnthanarak, MD $\bullet$ Pratumthani, Thailand- \\ Lennox Archibald, MD, FRCP • Alachua, FL \\ Shailen Banerjee, $\mathrm{PhD} \bullet$ Atlanta, GA \\ Elise M. Beltrami, MD, MPH • Atlanta, GA \\ Jo Anne Bennett, RN, PhD • New York, NY \\ David Birnbaum, $\mathrm{PhD}, \mathrm{MPH} \bullet$ Sidney, BC \\ Marc Bonten, MD • Utrecht, Netherlands \\ Christian Brun-Buisson, MD • Creteil, France \\ John P. Burke, MD • Salt Lake City, UT \\ David P. Calfee, MD, MS • New York, NY \\ Yehuda Carmeli, MD, MPH $\bullet$ Tel Aviv, Israel \\ Donald E. Craven, MD • Burlington, MA \\ Christopher Crnich, MD, MS • Madison, WI \\ Erika D'Agata, MD, MPH $\bullet$ Boston, MA \\ Daniel Diekema, MD • Iowa City, IA \\ Erik Dubberke, MD, MSPH $\bullet$ St. Louis, MO \\ Charles E. Edmiston, Jr., PhD • Milwaukee, WI \\ Mohamad Fakih, MD, MPH • Grosse Pointe Woods, MI \\ Petra Gastmeier, MD • Berlin, Germany \\ Jeffrey Gerber, $\mathrm{MD}, \mathrm{PhD} \bullet$ Philadelphia, PA \\ Dale N. Gerding, MD $\bullet$ Hines, IL \\ Donald A. Goldmann, MD • Boston, MA \\ Nicholas Graves, $\mathrm{PhD} \bullet$ Brisbane, Australia \\ Donna Haiduven, RN, PhD, CIC • Tampa, FL \\ Anthony D. Harris, MD, MPH $\bullet$ Baltimore, MD \\ Elizabeth Henderson. $\mathrm{PhD} \bullet$ Calgary, $\mathrm{AB}$ \\ David K. Henderson, MD $\bullet$ Bethesda, MD \\ Loreen A. Herwaldt, $\mathrm{MD} \bullet$ Iowa City, IA \\ Peter N. R. Heseltine, MD • Brea, CA \\ John A. Jernigan, MD, MS • Atlanta, GA \\ Mini Kamboj, MD • New York, NY
}

Infection Control \& Hospital Epidemiology (ISSN 0899-823X) is published monthly by Cambridge University Press, One Liberty Plaza, New York, NY 10006, USA.

\section{Editorial Office}

Communications should be addressed to the Editor, Infection Control \& Hospital Epidemiology, One Liberty Plaza, New York, NY 10006 (email: iche.managingeditor@cambridge.org. Contributors should consult the Instructions for Contributors, which is available at the journal's Web site.

\section{Advertising}

Please direct advertising inquiries to M. J. Mrvica Associates, 2 West Taunton Avenue, Berlin, NJ 08009 (e-mail: mjmrvica@mrvica.com; telephone: 856-768-9360, fax: 856-753-0064). Publication of an advertisement in Infection Control \& Hospital Epidemiology does not imply endorsement of its claims by the Society for Healthcare Epidemiology of America, by the Editor, or by Cambridge University Press.

\section{Permissions}

Articles may be copied or otherwise reused without permission only to the extent permitted by Sections 107 and 108 of the US Copyright Law. Permission to copy articles for personal, internal, classroom, or library use may be obtained from the Copyright Clearance Center (http://www.copyright.com, email: info@copyright.com). For all other uses, such as copying for general distribution, for advertising or promotional purposes, for creating new collective works, or for resale, please contact Cambridge University Press. Full details may be found at: www.cambridge.org/about-us/rights-permissions.

\section{Subscriptions}

The individual subscription rate for 2019 is \$273. Individuals have the option to order directly from Cambridge University Press. Institutional print + electronic and e-only subscriptions are available from Cambridge University Press and include unlimited online access; rates are tiered according to an institution's type and research output and may be reviewed at the journal's CJO homepage: cambridge.org/ICHE.

Please direct subscription inquiries and requests for back issues to Customer Services at Cambridge University Press, e-mail: subscriptions_newyork@ cambridge.org (USA, Canada, and Mexico) or journals@cambridge.org (outside of USA, Canada, and Mexico).

Postmaster: Send address changes to Infection Control \& Hospital Epidemiology, Cambridge University Press, One Liberty Plaza, New York, NY 10006 USA. 


\section{About the cover:}

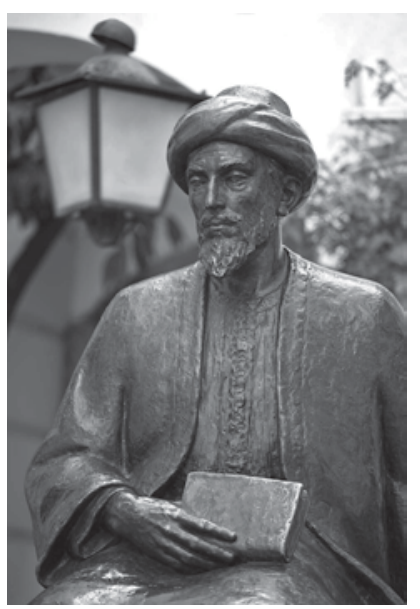

Since 2015, the cover format of each volume of Infection Control and Hospital Epidemiology has been clhanged to honor one of the many professionals through out history who recognized not only how disease might be spread but also how those principles could be applied to reduce health care associated infections.

Rabbi Moshe ben Maimon or Moses Maimonides (son of Maimon) was born in Cordoba, Spain, a center of intellectual and religious freedom, on March 30, circa 1135. Maimon ben Joseph, his father, was a prominent scholar, writer, and judge for Jewish religious courts. Maimonidesstudied with Averroes, aprominent physician-philosopher. In 1148, his familyleft Cordoba after a repressive dynasty, the Almohades Caliphate that ruled in Spain and North Africa during the 12 th and 13 th centuries, required that they either convert to Islam, emigrate, or be put to death. They wandered first to Fez, Morocco, and to Acco, Palestine, before finally settling in Old Cairo (Fostat), Egypt, circa 1165. His father and brother established a business selling precious stones, but soon after, his father died and his brother David perished in a shipwreck. Maimonides turned to medicine as a means to support both families. While only in his thirties, Maimonides was appointed as physician to the Court of the Sultan, and he served as head of the Jewish community in Cairo. During the Crusades, Maimonides' reputation as a healer was so great that King Richard the Lion hearted offered him a position as his personal physician.

Maimonides wrote many scholarly works on a variety of subjects ranging from biblical and Talmudic law to logic, science, and medicine. He embraced the use of careful scientific reasoning and eschewed mysticism. In his 10 books on medicine, Maimonides was an early advocate for the importance of hygiene, bathing, and the need for fresh air, clean water, a healthy diet, as well as proper disposal of refuse and placement of toilets far away from living quarters. Maimonides was an early "steward" who recommended non pharmacological interventions first. He also noted where evidence was lacking and further investigation was needed before recommendations could be made. Many of the concerns and observations that Maimonides made more than 800 years ago remain highly relevant to the field of infection prevention and control today.

Maimonides died in Cairo on December 13, 1204 at the age of 69. Several legends are a scribed to Maimonides. It is unlikely that he wrote the Oathor Prayer of Maimonides. He is buried in Tiberias, Palestine, on the western shore of the Sea of Galilee in present-day Israel. However, this site was not chosen at random by a donkey that roamed free while bearing his body; Maimonides was interred at Tiberias at his request. Even today, Maimonides remains a highly regarded physician, philosopher, and scholar among Jewish, Arabic, and Christiancircles. 


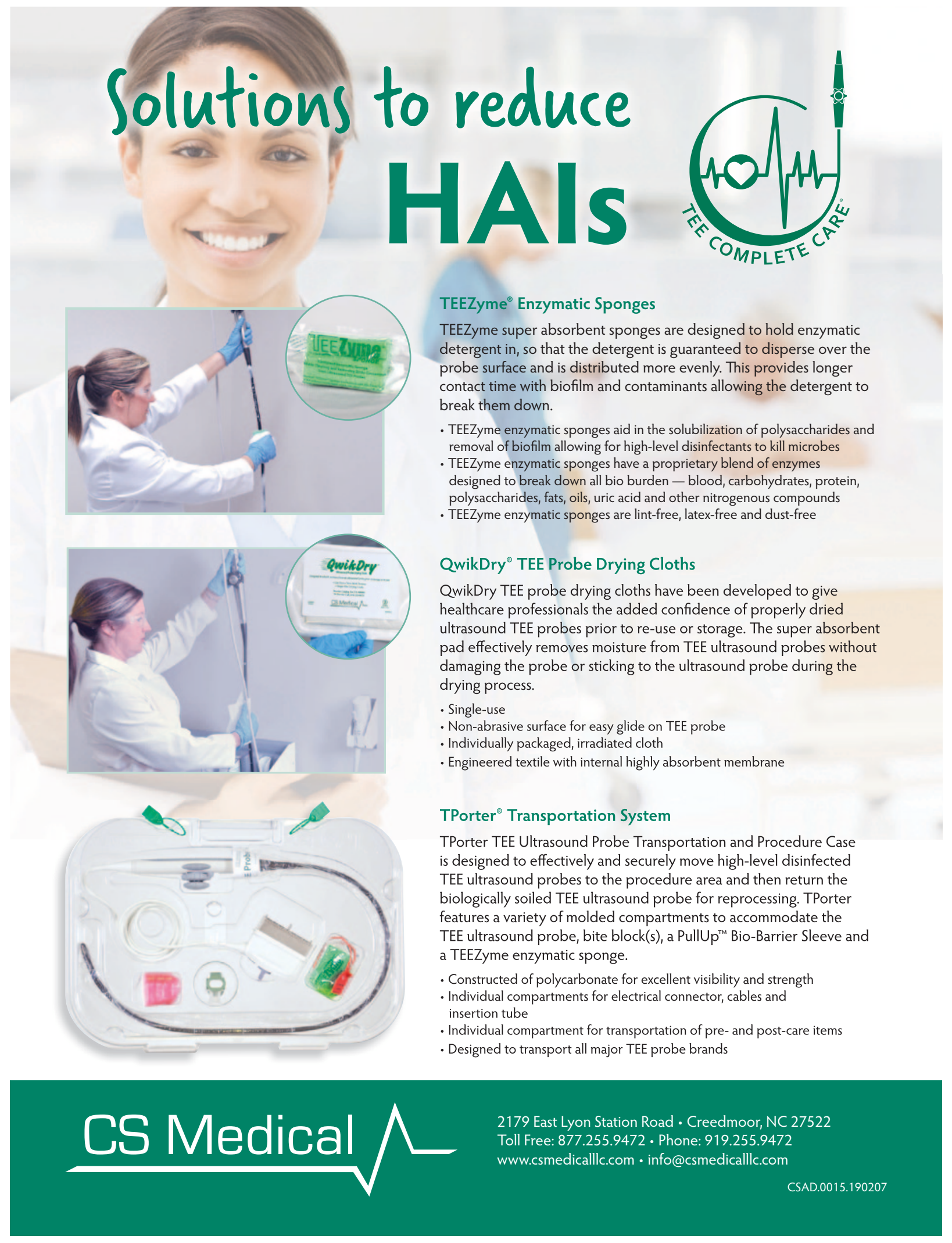

